\title{
Article \\ What Encourages Longer Educational Careers in Tertiary Education? A Three-Level Approach for the Case of Romanian Universities
}

\author{
Ana-Maria Zamfir ${ }^{1}$, Cristina Mocanu ${ }^{1}$ and Adriana AnaMaria Davidescu ${ }^{1,2, *(D)}$ \\ 1 Department of Education, Training and Labour Market, National Scientific Research Institute for Labour and \\ Social Protection, 010643 Bucharest, Romania; anazamfir2002@yahoo.com (A.-M.Z.); \\ mocanu@incsmps.ro (C.M.) \\ 2 Department of Statistics and Econometrics, Bucharest University of Economic Studies, \\ 010374 Bucharest, Romania \\ * Correspondence: adriana.alexandru@csie.ase.ro
}

check for updates

Citation: Zamfir, A.-M.; Mocanu, C.; Davidescu, A.A. What Encourages Longer Educational Careers in Tertiary Education? A Three-Level Approach for the Case of Romanian Universities. Int. J. Environ. Res. Public Health 2021, 18, 12864. https://doi.org/10.3390/ ijerph182312864

Academic Editor: Paul B. Tchounwou

Received: 31 October 2021

Accepted: 3 December 2021

Published: 6 December 2021

Publisher's Note: MDPI stays neutral with regard to jurisdictional claims in published maps and institutional affiliations.

Copyright: (C) 2021 by the authors Licensee MDPI, Basel, Switzerland. This article is an open access article distributed under the terms and conditions of the Creative Commons Attribution (CC BY) license (https:/ / creativecommons.org/licenses/by/ $4.0 /)$.

\begin{abstract}
Students' commitment and engagement in the educational process are shaped by a dense combination of factors, with effects on educational attainment and on the length of their educational careers. Decisions of prolonging education by enrolling in master's degrees are beneficial for both individuals and societies, as such programs provide higher levels of specialized skills Longer educational careers are favored by a mix of factors acting at the level of individual, university, or wider environment. We focus our study on exploring factors conducive for students' intentions to pursue master's degrees considering longer educational careers as desirable outcomes. Thus, this article investigates how the individual and environmental factors interplay and shape the predisposition of students to prolong their educational career by enrolling in master's degrees. For this, we applied three-level logistic regression models for a sample of 502 students enrolled in their final year of bachelor studies grouped by universities and universities grouped by counties. The empirical results revealed that the final grade, the father level of education, the type of working contract, and job seniority are individual-level determinants influencing the decision of enrolment in a master's program. At the university level, the type of university and the university performance score positively impact the students' decision to enroll in a master's program. At the county level, the empirical evidence pointed out the significance of determinants such as the proportion of students enrolled in bachelor studies; participation rate in education and training; employment level in high-technology sectors (HTC), total-knowledge intensive sectors (KIS), and knowledge-intensive high-technology sectors (KIS_HTC); proportion of persons with tertiary education employed in science and technology; proportion of scientists and engineers; local development; R\&D expenditure, personnel, and researchers in the business sector; average gross earnings; density of active firms; birth rate of companies; proportion of innovative enterprises or those introducing product innovations on the decision to enroll in a master's program.
\end{abstract}

Keywords: tertiary education; educational careers; three-level approach; logistic regression model; Romanian universities; educational survey

\section{Introduction}

We are part of a social system in which change fully characterizes each component part, including practically every action and approach undertaken within the social groups of affiliation, the individual human being thus both part of the change and its promoter. For change to respond to the needs and desires of social progress, it is mandatory to embed the right mix of skills [1].

Skills development is a lifelong process through which we acquire and upgrade our skills, competencies, and qualifications (relative to change), in line with the emerging needs 
of the labor market and society [2]. People need to possess key competences and basic skills (languages and digital skills), as well as relevant specific skills, as the needs of the labor market evolve. More recently, transversal skills (how to learn and take initiative, to work with others, and problem solving) became increasingly important for developing a successful career. Digital technology is transforming almost every aspect of our public, private, or professional lives. For every individual employee, student, and citizen, this technological innovation creates a demand for new and evolving digital skills. Ensuring the skills needed for the workforce is a key component in meeting the three priorities of the Europe 2020 Strategy.

Educational systems need to provide the necessary skills, which include specialized competences, digital and transversal skills, media education, and communication in a foreign language. Harnessing the talents and potential of future employees is very important and requires better cooperation between the labor market and the education system, but also greater transparency in the labor market beyond traditional approaches that measure skills only through formal qualifications [1]. Enrolling in a graduate education program allows students to expand their knowledge in a specific field of study while also developing in ways to prepare them for their future career [3]. Sometimes, recently enlisting undergraduate students must choose which graduate school they ought to go to. Due to the complex nature of selecting a graduate program, undergraduate students must make their choice through reflection and recognizable proof of individual, scholarly, and career objectives [4].

The main aim of the article refers to educational decisions, with a focus on the transition from bachelor to master studies, exploring the individual, institutional, and local factors that shape the predisposition of bachelor students when enrolling in master's programs, considering that this decision is influenced by a dense combination of mechanisms.

In this context, our study is focused on the following research questions:

Q1: What is the role of individual factors (academic performances, familial circumstances, gender, age, area of residence, participation in labor market, and expected employment and earnings) in shaping students' intentions to pursue master's degrees?

Q2: Do university-level factors influence the propensity of students in enrolling in master's programs?

Q3: How does the wider economic and social environment determine the predispositions of students to pursue master's degrees?

Q4: Do the individual, university, and socio-economic factors interact in shaping students' intentions to pursue master's degrees?

Q5: Does the decision of enrolment to a master's program vary across universities? Across counties?

The choice to seek post-graduation instruction is a decision made by thousands of people after completion of their undergraduate degree [2]. When graduate students effectively complete their graduate degrees, they encounter an increment in profit and quality of life [5]. While the research field of graduate education and its determinants has grown in size and importance, few studies have focused on the factors shaping the enrolment in master's degrees. Moreover, not many studies on educational decisions have been carried out in Central and Eastern European and Balkan countries. The current paper is valuable for filling a gap in the current research, as no study has been carried out on identifying factors influencing the decision of enrolment to a master's program in Romanian universities. Romania represents an interesting case as a country with an emerging economy and expansion of education, including a raising participation in higher education.

The paper is structured as follows. The section of the literature review offers an overview of the most relevant studies concerning the drivers of the transition from bachelor to master studies, while Section 3 offers additional information about the data used in the analysis, providing also a brief description of the methodology used within the paper. Section 4 is dedicated to the presentation of the main results, highlighting also a sub-section 
of discussions in relation to the main findings. The paper ends with concluding remarks and highlights both limitations and recommendations for further study.

\section{Literature Review and Theoretical Framework}

"Higher education is considered as incubator of the technical progress as well as the provider of higher-level skills" ([6], p. 385). Thus, the topic of this article is related to the study of educational decisions, with a focus on the transition from bachelor to master studies. While earlier studies focused on the concept of student retention into higher education, recent theoretical frameworks rely on the idea that the choice of enrolment into master's degree is a new and distinct decision [2]. Educational decisions are shaped by a combination of mechanisms covering individual preferences and opportunities, together with the conditions that influence them. Hosler and Gallagher [7] developed the threephase college-going model in which the educational choice process includes a first stage called the predisposition phase. In this phase, students decide whether or not they want to continue their education by enrolling in a higher-level education program. This paper explores individual, institutional, and local factors that shape the predisposition of bachelor students to enroll in master's programs, considering that this decision is influenced by a dense combination of mechanisms. We develop our analysis in the framework of the cultural and social capital role, as well as of the human capital theory.

Considering the relevance of cultural and social capital for educational choices, previous studies found that various individual factors influence such decisions. One important factor is related to the previous academic performances of students. They influence expectations with respect to future academic success and perceived academic self-efficacy, and determine the predisposition of students to take risks related to enrolment in a higherlevel educational program [8,9]. Familial circumstances represent another group of factors shaping educational careers. On the one hand, students with higher family income display a higher probability to attain higher levels of education [10,11]. On the other hand, educational attainment of the students' parents represents a measure of their cultural capital that influence the probability of students to graduate in higher levels of education. Those having parents with higher levels of education register higher educational attainment $[9,12]$. Previous findings show that the education of parents also indirectly influence the enrolment in master's programs through characteristics of educational institutions, academic performances, and academic expectations [9]. The cultural model for the parents of the cohort covered in the survey was extensively a conservative one, characterized by higher ages and levels of education for the male partners within the married couples, as well as by low levels of births outside marriage. As our study addresses the decision of youth to extend their educational pathway, we considered the father's level of education as a better proxy for the stock of education existing within households.

Additionally, some socio-demographic characteristics such as gender, age, and race, as well as their residence area influence students' decisions to enroll in higher levels of education, including master's degrees $[10,13,14]$.

Another category of factors that influence educational careers are related to the characteristics of educational institutions [10]. According to the theory of students' retention [15], students experiencing a match between their motivations and abilities, and the academic and social qualities of educational institutions influence in a positive manner students academic and social integration. Previous studies found that the quality of the academic environment influences students' educational decisions [16]. Another characteristic of influence is the type of university. Students from research universities have a higher propensity for pursuing master's degrees than those enrolled in teaching-oriented universities [14]. Of course, the satisfaction of students with educational experience shapes their predisposition to continue education, while satisfaction is influenced by perceived performances and outcomes of educational institutions [17].

Another strand of factors shaping educational decisions are related to the human capital theory. According to this theory, education represents an investment in human 
capital that is driven by the expected economic returns [18-20]. Thus, education is seen as an investment that allows for the accumulation of knowledge and skills that provide people with better career prospects and access to higher earnings. Previous studies found that the demand for higher education is shaped by the unemployment level [12,21]. Additionally, educational decisions are influenced by expected earnings upon completion of a specific level of education [22,23], while situations of overeducation affect many higher education graduates [24]. Additionally, the major of students has been found to influence their enrolment in master's programs due to differences in the expected advantages [2]. Both expected employment prospects and the income associated with graduation are taken into consideration in educational decisions [12]. Higher expected earnings are conducive for enrolment in post-graduate education [22]. In addition, participation of students in the labor market influences their decision of enrolment in higher education levels [25] as they face a tradeoff between current potential earnings and prospective higher incomes expected after graduation.

The mix and interaction of individual and macro-level factors shaping educational decisions inspired scholars to develop multilevel models for studying this topic. In analyzing the determinants of university enrolment in Vietnam, Vu et al. [6] emphasized the relevance of household socioeconomic status, gender, ethnic group, migrant status, and urban/rural residence as individual-level predictors of participation, as well as the relevance of fertility stabilization, income distribution, and average education level as contextual predictors at the provincial level.

Beyene and Yimam [26] investigated the drivers of academic achievement in higher education universities by applying a multilevel approach, emphasizing that the university entrance exam result, sex, mother's education level, father's education level, drug use, number of assessments, and group study status are the most relevant determinants of academic achievement.

Using a qualitative methodology and two focus groups, Sturm ([27], p.122) identified the factors that most influence enrolment in graduate education: the "need of the graduate degree for a desired career, desire to gain qualifications that would result in more opportunities, the institution being able to meet financial concerns, and the personal touch/comfort they felt from the institution".

Students' commitment and engagement in the educational process are shaped by a dense combination of factors, with effects on educational attainment and the length of their educational careers. Many studies on educational decisions employ binomial logit models considering that students choose the most attractive option from two alternative choices $[12,28]$. Taking into account the multi-layers of factors shaping educational decisions, more recent studies apply multilevel models for studying the complex mechanisms that shape educational decisions, especially in relation to higher education [2]. Such multilevel models include different layers of factors from individual, education institution, and local labor market levels [2].

\section{Methodology and Data}

In order to capture the intention of enrollment to a master's program in the academic year of 2020/2021, data were gathered from an educational survey. Data collection took place in 2019 via a questionnaire-based survey among 502 students enrolled in their final year of bachelor studies. The survey covered students enrolled in engineering and social sciences in ten Romanian universities from five countries. Students have been asked to report their intentions of further pursuing a master's level degree in the school year of $2020 / 2021$. The survey also collected a variety of data on students' characteristics such as gender, age, area of residence, academic performance, parents' education, and relation to the labor market, as well as a set of subjective information regarding their expectations and perceptions on the monetary and non-monetary benefits brought by a master's degree. Additional information on the characteristics of educational institutions providing bachelor 
studies (performances of the university and supply of master's programs) have been retrieved from administrative sources.

For investigating other potential factors that could encourage longer educational careers in tertiary education, we structured a set of variables on three main pillars, namely labor market, higher education, and innovation, in order to capture how the specificities of the context could influence such a decision to continue the educational pathway. As the study is focused on the decision to pursue master's programs, we extended the list of variables characterizing the labor market in order to capture the demand for highly specialized skills (Table 1). Taking into account the fact that the counties selected in the analysis were representative for the regions and the fact that county-level variables were rather limited, we decided to complement our analysis, including also regionallevel indicators. Thus, the following were included: the ILO youth unemployment rate, vacancy rates, employment rate for ISCED 5-8, employment in high-technology sectors, employment in total knowledge-intensive services, employment in knowledge-intensive high-technology services, persons with tertiary education (ISCED) and those employed in science and technology, proportion of scientists and engineers, participation rate in education and training, intramural R\&D expenditure (GERD) in the higher education sector, intramural R\&D expenditure (GERD), the business enterprise sector, intramural $R \& D$ expenditure (GERD), the public sector, total R\&D personnel and researchers in the business sector, innovative firms, enterprises introducing product innovations, process innovations, and enterprises introducing product and process innovations. A detailed description of all the variables within the model is provided in Table 1.

Table 1. The main indicators used in the research analysis.

\begin{tabular}{|c|c|c|c|}
\hline Indicator & Code & Source & Period \\
\hline $\begin{array}{l}\text { The decision to apply to a master's program in } \\
\text { the academic year of } 2020 / 2021 \text { (dependent } \\
\text { variable) was measured using the following } \\
\text { question: "After completing your current } \\
\text { bachellor studies, do you plan to apply for a } \\
\text { master's degree program in the following } \\
\text { academic year?" This was coded as } 1 \text { for } \\
\text { students who answered 'yes' to the question and } \\
0 \text { otherwise. }\end{array}$ & Appl_master & Educational survey & 2019 \\
\hline \multicolumn{4}{|c|}{ Level 1 indicators } \\
\hline \multicolumn{4}{|c|}{ Student-related variables } \\
\hline $\begin{array}{l}\text { Gender: a dummy variable with a value of } 1 \text { for } \\
\text { women and } 2 \text { for men; }\end{array}$ & Gender & Educational survey & 2019 \\
\hline Age: a numerical variable (mean-centered: 22.07$)$ & Age & Educational survey & 2019 \\
\hline $\begin{array}{c}\text { Area of the usual residence: a dummy variable } \\
\text { with a value of } 1 \text { for urban areas and } 2 \text { for } \\
\text { rural areas. }\end{array}$ & Residence & Educational survey & 2019 \\
\hline $\begin{array}{l}\text { Graduation final grade of the previous school } \\
\text { year: a numerical variable (mean-centered: } 8.81 \text { ) }\end{array}$ & Final_grade & Educational survey & 2019 \\
\hline $\begin{array}{l}\text { The highest level of education of the father: a } \\
\text { categorical variable with a value of 1-low level } \\
\text { (ISCED 0-2: without education, primary } \\
\text { education, and lower secondary education); } \\
\text { 2--medium level (ISCED 3-4: upper secondary } \\
\text { education and post-secondary non-tertiary } \\
\text { education); and 3-high level (ISCED 5-8: } \\
\text { short-cycle tertiary education, bachelor's or } \\
\text { equivalent level, master's or equivalent level, } \\
\text { and doctoral or equivalent level). }\end{array}$ & Father_high_edu & Educational survey & 2019 \\
\hline
\end{tabular}


Table 1. Cont.

\begin{tabular}{|c|c|c|c|}
\hline Indicator & Code & Source & Period \\
\hline $\begin{array}{l}\text { Subjective income was measured using the } \\
\text { following question: "If you think about the total } \\
\text { monthly income of your household, how you } \\
\text { meet the needs?" This was coded as } 1 \text { for persons } \\
\text { who answered 'easy enough' to the question and } \\
2 \text { for persons who answered "with difficulty". }\end{array}$ & Subj_inc & Educational survey & 2019 \\
\hline $\begin{array}{l}\text { Type of contract: a categorical variable with a } \\
\text { value of } 1-\text { full-time, } 2 \text { - part-time, and } 3 \text {-not } \\
\text { working for salary or other cash income. }\end{array}$ & Empl_type & Educational survey & 2019 \\
\hline $\begin{array}{l}\text { Seniority—working experince: a numerical } \\
\text { variable (mean-centered: } 0.918)\end{array}$ & Seniority & Educational survey & 2019 \\
\hline $\begin{array}{l}\text { Full-time salary expected for a person who } \\
\text { graduated with a master's degree diploma: a } \\
\text { numerical variable (mean-centered: RON 3815) }\end{array}$ & Master_salary & Educational survey & 2019 \\
\hline $\begin{array}{l}\text { Share of unemployed expected for graduates } \\
\text { with a master's degree: a numerical variable } \\
\text { (mean-centered: } 10.04 \%)\end{array}$ & Unempl_master_degree & Educational survey & 2019 \\
\hline \multicolumn{4}{|c|}{ Level 2 indicators } \\
\hline \multicolumn{4}{|c|}{ University-related variables } \\
\hline $\begin{array}{l}\text { University type: a dummy variable with a value } \\
\text { of } 1 \text {-engineering or } 2 \text {-social. }\end{array}$ & Univ_type & Educational survey & 2019 \\
\hline $\begin{array}{l}\text { University score: a numerical variable } \\
\text { (mean-centered: 5.89) }\end{array}$ & Univ_score & $\begin{array}{l}\text { University Metaranking: } 2019 \\
\text { Ranking of Universities in Romania } \\
\text { (Available online: https://ad-astra.ro/ } \\
\text { wp-content/uploads/2019/11/ } \\
\text { Metarankingul_Universitar_2019.pdf } \\
\quad \text { (accessed on 3 August 2021)) }\end{array}$ & 2019 \\
\hline $\begin{array}{l}\text { Student number in the master's programs } \\
\text { (budget + fee): a numerical variable } \\
\text { (mean-centered: } 4582 \text { persons) }\end{array}$ & Univ_students & $\begin{array}{l}\text { The platform of the Integrated } \\
\text { Educational Register, Universities } \\
\text { Statistics (Available online: https: } \\
\text { / / rei.gov.ro/statistici-universitati-13 } \\
\text { (accessed on } 3 \text { August 2021)) }\end{array}$ & 2018-2019 \\
\hline $\begin{array}{l}\text { Number of master's programs: a numerical } \\
\text { variable (mean-centered: } 112 \text { ) }\end{array}$ & Master_progr_nb & $\begin{array}{l}\text { National Authority for Qualifications } \\
\text { (Available online: } \\
\text { http:/ / site.anc.edu.ro/statistica/ } \\
\text { (accessed on } 3 \text { August 2021)) }\end{array}$ & 2019 \\
\hline \multicolumn{4}{|c|}{ Level 3 indicators (all level 3 indicators have been mean-centered) } \\
\hline \multicolumn{4}{|c|}{ Labour maket indicators } \\
\hline ILO youth unemployment rate, $15-24$ years, $\%$ & ILO_UR & $\begin{array}{l}\text { Regional Labour Force, Tempo } \\
\text { database, NIS }\end{array}$ & 2018 \\
\hline Registered unemployed/100 employees & Unempl/employ & $\begin{array}{l}\text { Territorial statistics database, Tempo } \\
\text { database, NIS }\end{array}$ & 2018 \\
\hline Average gross earnings, $\mathrm{RON}$ & Ag_g_earnings & Tempo database, NIS & 2018 \\
\hline Vacancy rate for professionals, $\%$ & Vac_rate_prof & $\begin{array}{l}\text { Regional Labour Force, Tempo } \\
\text { database, NIS }\end{array}$ & 2019 \\
\hline $\begin{array}{l}\text { Vacancy rate for technicians and associate } \\
\text { professionals, } \%\end{array}$ & Vac_rate_tech_prof & $\begin{array}{l}\text { Regional Labour Force, Tempo } \\
\text { database, NIS }\end{array}$ & 2019 \\
\hline $\begin{array}{c}\text { Employment rate for ISCED 5-8, age } \\
15-64 \text { years, } \%\end{array}$ & Tertiary_empl & $\begin{array}{l}\text { Regional labour market } \\
\text { statistics, Eurostat }\end{array}$ & 2019 \\
\hline
\end{tabular}


Table 1. Cont.

\begin{tabular}{|c|c|c|c|}
\hline Indicator & Code & Source & Period \\
\hline $\begin{array}{l}\text { Employment in high-technology sectors HTC } \\
\text { (high-technology manufacturing and } \\
\text { knowledge-intensive high-technology services), } \\
\% \text { of total employment }\end{array}$ & Empl_HTC & $\begin{array}{l}\text { Regional Science and Technology } \\
\text { Statistics database, Eurostat }\end{array}$ & 2018 \\
\hline $\begin{array}{l}\text { Employment in total knowledge-intensive } \\
\text { services (KIS), \% of total employment }\end{array}$ & Empl_KIS & $\begin{array}{l}\text { Regional Science and Technology } \\
\text { Statistics database, Eurostat }\end{array}$ & 2018 \\
\hline $\begin{array}{l}\text { Employment in knowledge-intensive } \\
\text { high-technology services (KIS_HTC), \% of } \\
\text { total employment }\end{array}$ & Empl_KIS_HTC & $\begin{array}{l}\text { Regional Science and Technology } \\
\text { Statistics database, Eurostat }\end{array}$ & 2018 \\
\hline $\begin{array}{l}\text { Persons with tertiary education (ISCED) and } \\
\text { employed in science and technology, \% of } \\
\text { active population }\end{array}$ & Tert.Ed.ST_empl & $\begin{array}{l}\text { Regional Science and Technology } \\
\text { Statistics database, Eurostat }\end{array}$ & 2018 \\
\hline Scientists and engineers, $\%$ of active population & SCT_ENG & $\begin{array}{l}\text { Regional Science and Technology } \\
\text { Statistics database, Eurostat }\end{array}$ & 2018 \\
\hline $\begin{array}{l}\text { Density of active firms, } \% \text { of active firms by } \\
1000 \text { people in the population }\end{array}$ & Firm_density & Tempo database, NIS & 2018 \\
\hline $\begin{array}{l}\text { Birth rate: number of enterprise births in the } \\
\text { reference period }(\mathrm{t}) \text { divided by the number of } \\
\text { enterprises active in } \mathrm{t}-\%\end{array}$ & Birth_rate & $\begin{array}{l}\text { Regional Business Demography } \\
\text { Statistics database, Eurostat }\end{array}$ & 2017 \\
\hline $\begin{array}{l}\text { Share of high growth enterprises measured in } \\
\text { employment: number of high growth enterprises } \\
\text { divided by the number of active enterprises with } \\
\text { at least } 10 \text { employees-\% }\end{array}$ & High_growth_enter & $\begin{array}{l}\text { Regional Business Demography } \\
\text { Statistics database, Eurostat }\end{array}$ & 2017 \\
\hline $\begin{array}{l}\text { Nominal GDP per capita, thousand } \\
\text { RON/inhabitant }\end{array}$ & County level & Tempo database, NIS & 2019 \\
\hline & Higher education indicato & & \\
\hline $\begin{array}{l}\text { Students enrolled in bachelor studies, } \% \text { of total } \\
\text { enrolled school-aged population }\end{array}$ & Stud_prop_bach & Tempo database, NIS & 2018 \\
\hline $\begin{array}{l}\text { Students enrolled in bachelor studies of full-time } \\
\text { education, } \% \text { of total students enrolled in } \\
\text { bachelor studies }\end{array}$ & Stud_prop_bach_full_time & Tempo database, NIS & 2018 \\
\hline $\begin{array}{l}\text { Number of tertiary education degree } \\
\text { graduates (bachelor) }\end{array}$ & Grad_Bach & Tempo database, NIS & 2017 \\
\hline $\begin{array}{l}\text { Number of tertiary education degree graduates } \\
\text { (bachelor) of full-time education }\end{array}$ & Full_time_grad_bach & Tempo database, NIS & 2017 \\
\hline $\begin{array}{l}\text { Participation rate in education and training (last } \\
\text { four weeks) representing share of the population } \\
\text { aged 25-64 years that received formal or } \\
\text { non-formal education or training (during the } \\
\text { four weeks preceding the survey), \% }\end{array}$ & E\&T_part_rate & $\begin{array}{l}\text { Regional Education Statistics } \\
\text { database, Eurostat }\end{array}$ & 2019 \\
\hline \multicolumn{4}{|c|}{ Innovation indicators } \\
\hline \multicolumn{4}{|c|}{ Investments } \\
\hline $\begin{array}{l}\text { Expenditures for education financed from the } \\
\text { local budget (RON/inhabitant) }\end{array}$ & Loc_budg_exp_ed & Territorial Statistics database, NIS & 2018 \\
\hline $\begin{array}{l}\text { Intramural R\&D expenditure (GERD) in the } \\
\text { higher education sector, } \% \text { of GDP }\end{array}$ & R\&D_exp_educ_s & $\begin{array}{l}\text { Regional Science and Technology } \\
\text { Statistics database, Eurostat }\end{array}$ & 2017 \\
\hline $\begin{array}{l}\text { Intramural R\&D expenditure (GERD), the } \\
\text { business enterprise sector, \% of GDP }\end{array}$ & R\&D exp_bus_s & $\begin{array}{l}\text { Regional Science and Technology } \\
\text { Statistics database, Eurostat }\end{array}$ & 2017 \\
\hline $\begin{array}{l}\text { Intramural R\&D expenditure (GERD), the public } \\
\text { sector, \% of GDP }\end{array}$ & R\&D exp_pub_s & $\begin{array}{l}\text { Regional Science and Technology } \\
\text { Statistics database, Eurostat }\end{array}$ & 2017 \\
\hline
\end{tabular}


Table 1. Cont.

\begin{tabular}{cccc}
\hline Indicator & Code & Source \\
\hline $\begin{array}{c}\text { Total R\&D personnel and researchers, the } \\
\text { business sector, as percentage of total } \\
\text { employment-numerator in full-time equivalent } \\
\text { (FTE), } \%\end{array}$ & $\begin{array}{c}\text { R\&D } \\
\text { personnel-bus_S }\end{array}$ & $\begin{array}{c}\text { Regional Science and Technology } \\
\text { Statistics database, Eurostat }\end{array}$ \\
\hline $\begin{array}{c}\text { Innovation activities } \\
\text { Innovative enterprises as a percentage of } \\
\text { total enterprises }\end{array}$ & Innov_enterp & Tempo database, NIS \\
\hline $\begin{array}{c}\text { Enterprises introducing product innovations as a } \\
\text { percentage of total enterprises } \\
\text { (only product innovators) }\end{array}$ & Product_innov & Tempo database, NIS \\
\hline $\begin{array}{c}\text { Enterprises introducing process innovations as a } \\
\text { percentage of total enterprises }\end{array}$ & Process_innov & Tempo database, NIS \\
\hline $\begin{array}{c}\text { Enterprises introducing product and process } \\
\text { innovations as a percentage of total enterprises }\end{array}$ & Product_Process-innov & Tempo database, NIS \\
\hline
\end{tabular}

\section{Multilevel Econometric Modelling}

In order to identify the main determinants of Romanian students' intention of applying to a master's program, three-level logistic regression analysis based on the hierarchical structure of the data, with individuals (level 1) grouped by universities (level 2) and universities grouped by counties (level 3), was applied. The command in STATA 15 for the estimation of multilevel logistic regression models is xtmelogit. This type of analysis uses individual-level variables and explores whether each university size-level independent variable together with county level indicators is significantly associated with the intention of applying to a master's program.

Thus, by using a three-layer multilevel model, we captured the relative importance of universities and labor market variables as influences on the decision to apply to a master's program, paying particular attention to the assessment of potential causal effects of universities performances and local labor market opportunities. The main hypothesis behind the model is that individual, university, and socio-economic factors interact in shaping students' intentions to pursue master's degrees.

The conceptual framework of the main determinants for the intention of applying to a master's program is presented in Figure 1.

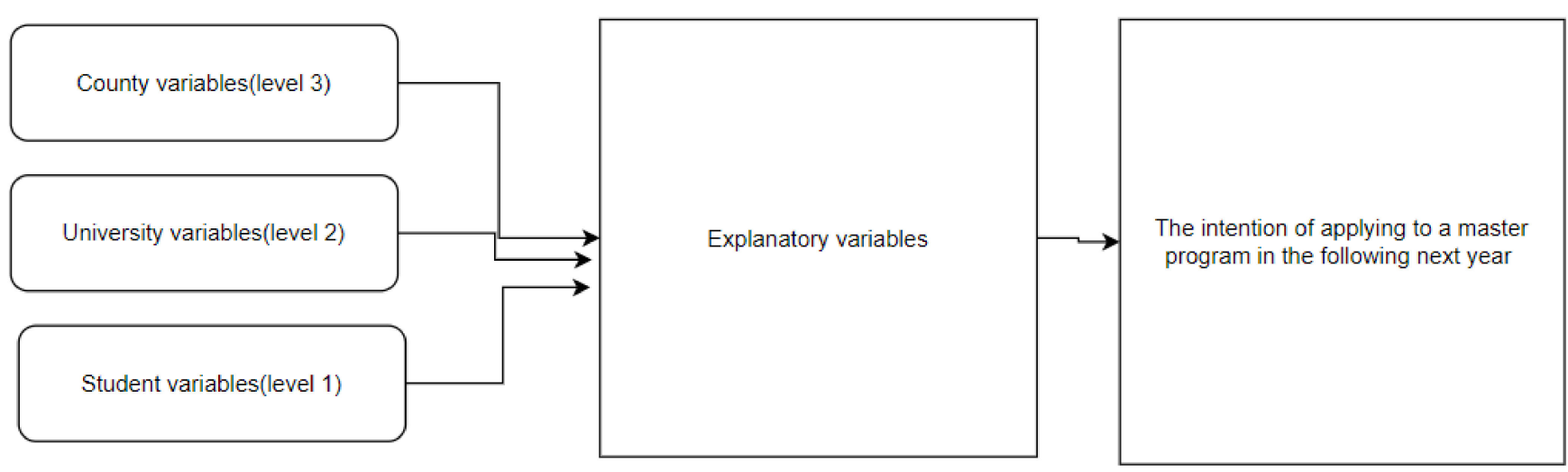

Figure 1. Conceptual framework of the main determinants for the intention of applying to a master's program.

The methodology of building the three-level models followed a stepwise approach. The first stage implied the estimation of a baseline random intercept model with no explanatory variables in order to identify whether a multilevel approach was appropriate. 
This model included only an intercept as well as university and county random effects, and an individual-level residual error term; the model makes no adjustments for predictor variables.

$$
\log \left(\frac{\pi_{i j k}}{1-\pi_{i j k}}\right)=\beta_{0}+v_{k}+u_{j k}+e_{i j k}
$$

$v_{k} \sim N\left(0, \sigma_{v}^{2}\right)$

$u_{j k} \sim N\left(0, \sigma_{u}^{2}\right)$

$e_{i j k} \sim N\left(0, \sigma_{e}^{2}\right)$

where the log odds are the logarithm of the odds (i.e., the ratio between a probability value (Phi) and its complementary) for individual $i(i=1, \ldots, 476)$ in university $j(j=1, \ldots 10)$ and in county $k(k=1, \ldots, 5) ; \beta_{0}$ is the mean across all counties; $v k$ is the effect of county $k ; u j k$ is the effect of university $j$; and eijk is the individual-level residual error term. The county, university effects, and the individual level residual errors are assumed independent and normally distributed with zero means and constant variances.

In interpreting variance components in multilevel models, we considered the variance partition coefficients (VPCs), which report the proportion of the observed response variation that lies at each level of the model hierarchy (Leckie, [29]). They therefore allowed us to establish the relative importance of universities, counties, and students as sources of variation of students' decision to enroll in a master's program.

The second stage involved constructing a model at first-level (i.e., individual-level and university) variables in an attempt to understand their effects and thus to test the impact of individual characteristics:

$$
\log \left(\frac{\pi_{i j k}}{1-\pi_{i j k}}\right)=\beta_{0}+\beta_{1} \cdot X_{i j k}+\beta_{2} \cdot X_{j k}^{\prime}+v_{k}+u_{j k}+e_{i j k}
$$

$$
\begin{aligned}
& v_{k} \sim N\left(0, \sigma_{v}^{2}\right) \\
& u_{j k} \sim N\left(0, \sigma_{u}^{2}\right) \\
& e_{i j k} \sim N\left(0, \sigma_{e}^{2}\right)
\end{aligned}
$$

In the third step, the logit random intercept model specification, including individual and university-level explanatory variables, as well as county-level explanatory variables, is the following:

$$
\log \left(\frac{\pi_{i j k}}{1-\pi_{i j k}}\right)=\beta_{0}+\beta_{1} \cdot X_{i j k}+\beta_{2} \cdot X^{\prime}{ }_{j k}+\beta_{3} \cdot X^{\prime \prime}{ }_{k}+v_{k}+u_{j k}+e_{i j k}
$$

$$
\begin{aligned}
& v_{k} \sim N\left(0, \sigma_{v}^{2}\right) \\
& u_{j k} \sim N\left(0, \sigma_{u}^{2}\right) \\
& e_{i j k} \sim N\left(0, \sigma_{e}^{2}\right)
\end{aligned}
$$

As in any regression model, we can include interaction effects which allow for the possibility that the effect of one explanatory variable on the outcome can depend on the value of another explanatory variable. Furthermore, it was worth to test if the effect of contextual county factors on the decision of applying to a master's program depended on the type of university (engineering vs. social). Therefore, in the fourth step, different random intercept models with cross-level interactions were estimated.

$$
\begin{aligned}
& \log \left(\frac{\pi_{i j k}}{1-\pi_{i j k}}\right)=\beta_{0}+\beta_{1} \cdot X_{i j k}+\beta_{2} \cdot X^{\prime}{ }_{j k}+\beta_{3} \cdot X^{\prime \prime}{ }_{k}+\beta_{4} \cdot X^{\prime}{ }_{j k} \cdot X^{\prime \prime}{ }_{k}+v_{k}+u_{j k}+e_{i j k} \\
v_{k} & \sim N\left(0, \sigma_{v}^{2}\right) \\
u_{j k} & \sim N\left(0, \sigma_{u}^{2}\right) \\
e_{i j k} & \sim N\left(0, \sigma_{e}^{2}\right)
\end{aligned}
$$


The general scheme of three-level models for applying to a master's program is displayed in Figure 2. Different specifications of three-level logistic models were estimated in order to overcome the issue of multi-collinearity, as some of the university-level and county-level variables could be correlated. The software used for the estimation was STATA version 15 [30].

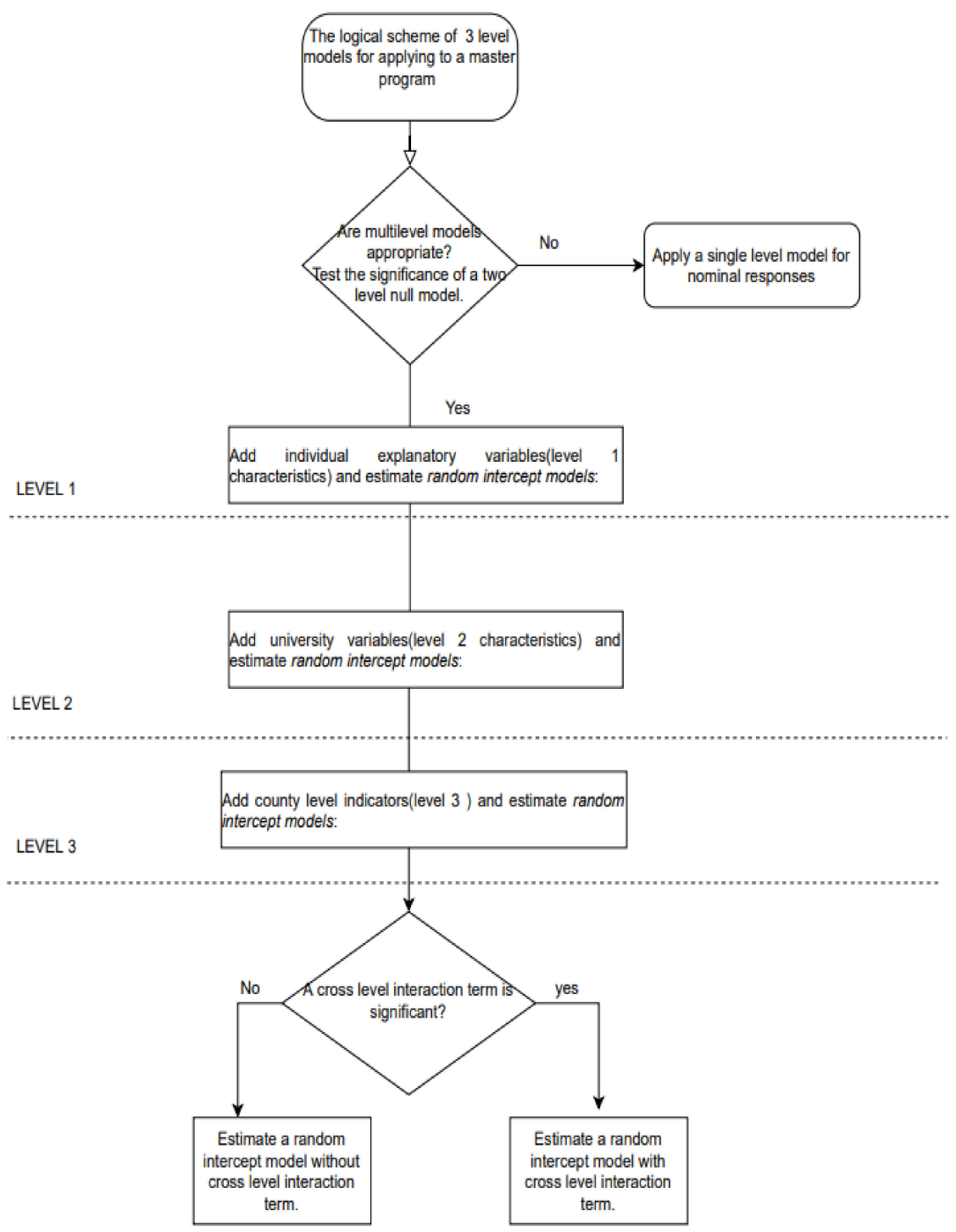

Figure 2. The general scheme of three-level models for applying to a master's program.

\section{Results}

\subsection{Descriptive Results}

From the total of 502 respondents, the distribution of students among five counties was balanced, while the gender distribution revealed that almost $54.38 \%$ were women, living in urban area, and with the average age of 21.8 years old. Regarding the highest education level of the father, the majority of the respondents declared to be at a medium level (67.13\%; Table 2).

The average grade among the interviewed students was 8.81 , with only $25 \%$ of the students having finished their studies with a grade higher than 9.4. There are significant differences regarding the final grade among the universities included in the sample, wherein the highest final grade was registered for the University of Agronomic Sciences and Veterinary Medicine, while at the opposite end was Transylvania University. Statis- 
tically significant discrepancies were highlighted also at the county level, with Suceava being the county with the highest final grade, while Brasov occupied the last place.

Table 2. The decision of applying to a master's program among students from different universities and from different counties.

\begin{tabular}{|c|c|c|c|c|c|c|c|c|c|c|}
\hline \multirow{3}{*}{ University } & \multicolumn{2}{|c|}{ Brasov } & \multicolumn{2}{|c|}{ Bucharest } & \multicolumn{2}{|c|}{ Cluj } & \multicolumn{2}{|c|}{ Dolj } & \multicolumn{2}{|c|}{ Suceava } \\
\hline & $\begin{array}{r}\text { Int } \\
\text { App } \\
\text { Maste }\end{array}$ & $\begin{array}{l}\text { n of } \\
\text { g to a } \\
\text { rogram }\end{array}$ & $\begin{array}{r}\text { Inten } \\
\text { Apply } \\
\text { Ma } \\
\text { Pro }\end{array}$ & $\begin{array}{l}\text { on of } \\
\text { ig to a } \\
\text { er's } \\
\text { ram }\end{array}$ & $\begin{array}{r}\text { Inten } \\
\text { Apply } \\
\text { Ma } \\
\text { Pro }\end{array}$ & $\begin{array}{l}\text { on of } \\
\text { ig to a } \\
\text { er's } \\
\text { ram }\end{array}$ & $\begin{array}{r}\text { Inte } \\
\text { Appl } \\
\text { M } \\
\text { Pr }\end{array}$ & $\begin{array}{l}\text { in of } \\
\text { g to a } \\
\text { r's } \\
\text { im }\end{array}$ & $\begin{array}{r}\text { Inte } \\
\text { App } \\
\text { M } \\
\text { Pr }\end{array}$ & $\begin{array}{l}\text { n of } \\
\text { to a } \\
\text { r's } \\
\text { im }\end{array}$ \\
\hline & No & Yes & No & Yes & No & Yes & No & Yes & No & Yes \\
\hline $\begin{array}{l}\text { Bucharest Academy of } \\
\text { Economic Studies }\end{array}$ & & & $65.71 \%$ & $34.29 \%$ & & & & & & \\
\hline $\begin{array}{l}\text { National University of } \\
\text { Political Studies and } \\
\text { Public Administration }\end{array}$ & & & $58.33 \%$ & $41.67 \%$ & & & & & & \\
\hline $\begin{array}{l}\text { Babes Bolyai University } \\
\text { University of Agronomic }\end{array}$ & & & & & $66.67 \%$ & $33.33 \%$ & & & & \\
\hline $\begin{array}{l}\text { Sciences and Veterinary } \\
\text { Medicine of Bucharest }\end{array}$ & & & $0.00 \%$ & $100 \%$ & & & & & & \\
\hline University of Bucharest & & & $28.57 \%$ & $71.43 \%$ & & & & & & \\
\hline University of Craiova & & & & & & & $49 \%$ & $51 \%$ & & \\
\hline Politehnica University & & & $4.26 \%$ & $95.74 \%$ & & & & & & \\
\hline $\begin{array}{c}\text { Ştefan cel Mare } \\
\text { University of Suceava }\end{array}$ & & & & & & & & & $46 \%$ & $54 \%$ \\
\hline $\begin{array}{c}\text { Technical University of } \\
\text { Cluj-Napoca }\end{array}$ & & & & & $46.43 \%$ & $53.57 \%$ & & & & \\
\hline $\begin{array}{c}\text { Transilvania University } \\
\text { Total }\end{array}$ & $43 \%$ & $57 \%$ & & & & & & & & \\
\hline
\end{tabular}

Source: own calculation.

As expected, most of the students declared not having significant work experience, with only $20 \%$ reporting at most two years of employment experience. At the level of the whole sample, only $15 \%$ of the respondents declared to have a full-time working contract and $22 \%$ declared to work on the basis of a part-time contract.

Data related to the subjective income show that $63 \%$ of the respondents declared that they manage their current expenses rather easily, referring to the total monthly income of the household.

In analyzing respondents' perceptions of the potential benefits of completing a master's program, most of them considered that the difference in terms of salary between a bachelor's degree and master's degree is between RON 500 and RON 1000, with statistically significant differences among counties (RON 780 in Suceava and only RON 430 in Cluj). Therefore, the average expected salary for a person with a master's degree was RON 3815, with significant differences among counties (RON 4020 for Cluj and RON 3600 in Bucharest).

In analyzing respondents' perceptions related to the number of unemployed individuals with a bachelor's degree vs. master's degree, the majority of them considered that having an additional diploma does not decrease the probability of being unemployed. For $43 \%$ of them, the difference in terms of the unemployment proportion with a master's degree vs. bachelor's degree is zero, while only $19 \%$ of them agreed that an additional diploma could decrease the number of unemployed individuals only by $5 \%$. Therefore, the average proportion of unemployed persons with a master's degree was 10\%, with statistically significant discrepancies among counties (13.35\% in Cluj and $7.36 \%$ in Suceava).

From the university side perspective, the study equally considered engineering and social universities, with different educational performances. Therefore, the highest institutional score was registered by Babes-Bolyai University, followed by the University of 
Bucharest and Politehnica University, while in terms of students enrolled in master's programs and the number of master's programs, at first place are the University of Bucharest, Babes-Bolyai University, and Politehnica University.

Additionally, at the county level, there were significant discrepancies, with Bucharest and Cluj being the counties with the highest level of institutional performance in terms of university score, while in terms of the number of students enrolled in master's programs and the number of master's programs, Cluj and Bucharest occupied the first place, with Suceava at the opposite end.

Among the students from different universities, the overall decision of applying for a master's program in the next academic year was favorable, as $53.6 \%$ of the respondents declared that they have the intention to continue their educational career following the courses of a master's program in the next year. The results of the Kruskal-Wallis test revealed that there was a highly statistically significant difference in the decision of applying to a master's program among students from different universities, with a higher associated probability for those one from Babes-Bolyai University.

In analyzing the decision of applying for a master's program in different universities and counties, the empirical results of the Kruskal-Wallis test emphasized statistically significant differences, with Bucharest being the county with the highest proportion of students wishing to continue their specialization following a master's program, while at the opposite side was Cluj with the lowest proportion of students. Significant differences in the enrolment intentions between students from different universities and counties support the development of a three-level model incorporating individual factors as well as university and county-level characteristics.

\subsection{The Main Results of the Estimated Models}

A three-level model was used to allow for a correlation between the intention of individuals living in the same country to apply for a master's program and the intention to explore the extent of between-county variations in master's program enrollment intentions with students nested in universities and universities nested in counties.

The first stage required the estimation of a baseline random intercept model, with no explanatory variables, used for proofing whether this multilevel technique is adequate. This stage revealed that the log-odds of enrollment in a master's program for an 'average' university from an 'average 'county is estimated to be $\beta_{0}=0.293$. The between-county variance of the log-odds of enrollment in a master's program is estimated to be 0.23 , while the between-university variance of the log-odds of enrollment in a master's program is estimated as 0.809 .

The LR test has been used to compare the current model to a single-level model with no county effects and no university effects. The high value of the test (Chi-square test $=33.87$ with a $p$-value $=0.000$ ) revealed that there is a significant variation between universities and counties in the proportion of those applying for a master's program. The three-level model therefore offers a significantly better fit to the data than the singlelevel model.

Taking into account the between-university variance of 0.809 , the variance partition coefficient (VPC) is $19.73 \%$ (the VPC is calculated as $0.809 /(0.809+3.29)=0.1973$, thus almost $20 \%$ of the residual variation in the propensity of enrollment in a master's program is attributable to unobserved university characteristics), indicating that almost $20 \%$ of the variance in applying to a master's program can be attributed to differences between universities rather than counties.

Furthermore, the variance partition coefficient (VPC) based on the between-county variance $(0.23)$ is $6.53 \%$ (as $0.823 /(0.23+3.29)=0.1973$, with almost $7 \%$ of the residual variation in the propensity of enrollment in a master's program is attributable to unobserved county characteristics).

After testing and revealing that the multilevel mixed-effects models are the appropriate ones, the second step is to add student-level predictor variables in Model I as well as 
university-level predictor variables in Models II, III, and IV, in such a way as for first-level and second-level variables, in order to capture the effects of these levels on the intention of following a master's program, while Models V-XVIII displayed also county-level predictors together with the cross-level interaction terms.

Table 3 reports the results of the random intercept models for all models. The empirical results for the individual-level variables pointed out that variables such as graduation final grade, the level of education of the father, seniority, or the type of working contract significantly influenced the decision of applying to a master's program in the near future. Thus, those who have finished their bachelor studies with a high final grade are significantly more inclined to apply for a master's degree, while the highest level of education of the father contributed also to the decision of applying to a master's program, which is a similar educational route to the father, creating the same decision also for the student most likely because the student has been inspired by their parent's academic achievement and academic feedback in their academic journey [26].

In all models, seniority decreased the probability of enrollment in a master's program, as usually students who started working during college are significantly less inclined to follow the courses of a master's program. This is not seen, in particular, for those working with a full-time contract compared to those ones not working, as individuals working full-time are significantly more inclined to apply for a master's program compared to those ones who work based on a part-time contract.

However, we have proved a lack of statistical significance for the association between gender, age, subjective income, residence area, the perceptions related to the full-time salary of a person who graduated with a master's degree diploma, and the share of unemployed with a master's degree.

In order to respond to the main research questions and keeping in mind that the university-level variables taken into account are correlated, three alternative models (Models II-IV) were estimated, offering additional information about how university-level indicators (performance score, type of university, number of students in the master's programs, and the number of master's programs) can influence the decision of the enrollment of a certain student in a master's program in the near future. The empirical results highlighted that the decision of Romanian students to enroll in a master's program depends on the university performance score and university type, as key university-level variables, and not on the number of students in the master's programs or the number of programs. Therefore, students are more inclined to choose the university based on the overall meta ranking, with students from engineering universities being more inclined to enroll in a master's program.

In order to provide more detailed perspectives on how the decision of enrollment in a master's program differs, taking into account both the differences between universities and between counties, and considering that county-level indicators are correlated, Table 3 reports the results of the random intercept models that include the individual-level and university-level variables for Models I-IV and also county-level predictors for Models V-VXIII, together with the cross-level interaction terms.

The empirical results clearly proved that the intention of applying to a master's program does not differ according to gender, age, residence area, subjective income, perceptions related to the full-time salary of a person with a master's diploma, the proportion of unemployed persons with a master's diploma, the number of students in the master's programs, or the number of master's programs.

In order to respond to Q1, at the individual level, this decision is more likely influenced by the final grade, high level of education of the father, and work seniority together with the full-time working contract, and the significance of these variables were preserved in all models.

Therefore, students with high average final grades are more inclined to continue their education by applying for a master's degree and the high level of education of the father is associated with a higher probability of enrolment. If the father has a high level of education, this will increase the probability of continuing the educational career of the child. 
If the work seniority acts by significantly decreasing the probability of enrolment into a master's program, as individuals already accumulating experience in the workplace are no longer inclined to apply for a master's degree, things differ in terms of the employment contract type. More specifically, it can be highlighted that those students working with a full-time contract tend to be more inclined to apply for a master's program compared to those who do not work.

It is worth mentioning that individual-level variables such as subjective income, the full-time salary of a person who graduated with a master's degree diploma, and the share of unemployed with a master's degree do not exhibit any statistical influence on the decision to enroll in a master's program considering the lack of significance preserved in all the'models.

With respect to university-level indicators and in order to respond to $Q 2$, the empirical results highlighted the statistical significance of all the estimated models of university type and university score on the intention of continuing the educational route. Furthermore, students from a social university are less inclined to apply to a master's program compared to those from an engineering university. The university score positively impacts the intention of applying to a master's program, with students being interested in selecting a higher performing university.

Finally, in order to assess the main determinants from the county level on the intention of applying to a master's program together with the cross-level interaction term, thirteen alternative models (Models V-XVIII) are presented in the Table 3. It is worth mentioning that a significantly higher number of specifications were tested, with some of them suffering from a lack of statistical significance; only those with statistical significance are displayed in Tables 3 and 4.

At the county level, the empirical evidence offers valuable information for research question Q3, proving the statistical significance of three pillars of the determinants: educationspecific determinants; labor market-specific determinants; and innovation-related indicators.

Thus, among the educational indicators proving to empirically influence the decision of enrolment in a master's program, we can mention the proportion of students enrolled in bachelor studies and the participation rate on education and training. Thus, an increased proportion of students enrolled in bachelor studies decreases the probability of enrolment in future master's program because, in the process of expanding education, the perception is that the educational premium is no longer as high and they no longer find the motivation to continue their studies. However, in the case of engineering university students, an increase in the proportion of enrolled students in bachelor studies increases the probability of applying to a master's program in the near future.

The participation rate on education and training manifested a positive and statistically significant impact on the intention of enrolment in a master's program.

Among labor market indicators, the empirical results proved a positive and statistically significant impact on the decision of applying to a master's program regarding a higher level of employment in high-technology sectors (HTC) or total-knowledge intensive sectors (KIS), or both (knowledge-intensive high-technology sectors (KIS_HTC)) as well as a higher proportion of persons with tertiary education employed in science and technology; a higher proportion of scientists and engineers; a higher level of local development; and a higher R\&D expenditure, number of personnel, and number of researchers in the business sector.

Therefore, all these county-level determinants positively influencing the decision of continuing the educational career of a student represents a specificity of the labor market, requiring specialized employees (high-skilled employees) and capturing the formal creation of new knowledge within firms, most likely in science-based sectors where most new knowledge is created in or near R\&D laboratories.

In addition, factors such as the average gross earnings, the density of active firms together with the birth rate of companies, the proportion of innovative enterprises, as well as those ones introducing product innovations tend to decrease the probability of continuing the educational career and attract students to the labor market. Innovative 
enterprises are enterprises launching new or significantly improved products (good or service) on the market or enterprises which introduced new or significantly improved processes, new organizational methods, or marketing methods. A product innovation is the market introduction of a new or significantly improved good or service with respect to its capabilities, user friendliness, components, or sub-systems.

Thus, when the birth rate of enterprises and density of active firms is relatively high, as well as in the case of a high average gross earnings, students will be less inclined to continue their educational pattern.

Another important result refers to the fact that the share of innovative enterprises and the share of enterprises introducing product innovations, representing a proxy for the innovative labor market and job creation, negatively impact the decision of applying to a master's program.

Until now, the models assumed that the contextual effect of different determinants is the same for all students regardless of the university type (engineering vs. social). At this stage, we have modified this assumption, allowing for the effect of the student proportion enrolled in bachelor studies and participation rate on the education and training, regarding the decision of applying to a master's program, to depend on the university type, including an interaction between university type and student proportion as cross-level interactions or the participation rate on education and training in the model.

The empirical results of Model V revealed that the marginal effect of the student proportion enrolled on bachelor studies on the decision to apply for a master's program positively and significantly depends on the university type. Thus, the student proportion enrolled in bachelor studies positively influenced the decision of applying for a master's program more effectively for students from engineering universities compared to those from social sciences universities.

The effect of student participation in education and training on the decision of applying to a master's program depends on the university type in Model VI; the empirical results revealed that the marginal effect of lifelong learning on the decision to apply for a master's program negatively and significantly depends on the university type. Thus, an increase in the student participation rate of education and training negatively influenced the decision of applying for a master's program more effectively for students from engineering universities compared to those from social sciences universities.

The empirical results of most of the models pointed out the statistical significance of the contextual effect of average gross earnings on the decision to apply for a master's program more effectively for students from engineering universities compared to those from social sciences universities. Therefore, students from engineering universities with high earnings are more inclined to enroll in a master's program. 
Table 3. Multilevel mixed-effects logistic regression models (random intercept models) of the enrolment decision of Romanian students to a master's program.

\begin{tabular}{|c|c|c|c|c|c|c|c|c|c|c|c|c|c|c|c|c|}
\hline & \multicolumn{2}{|c|}{ Model I } & \multicolumn{2}{|c|}{ Model II } & \multicolumn{2}{|c|}{ Model III } & \multicolumn{2}{|c|}{ Model IV } & \multicolumn{2}{|c|}{ Model V } & \multicolumn{2}{|c|}{ Model VI } & \multicolumn{2}{|c|}{ Model VII } & \multicolumn{2}{|c|}{ Model VIII } \\
\hline & $\beta$ & $\exp (\beta)$ & $\beta$ & $\exp (\beta)$ & $\beta$ & $\exp (\beta)$ & $\beta$ & $\exp (\beta)$ & $\beta$ & $\exp (\beta)$ & $\beta$ & $\exp (\beta)$ & $\beta$ & $\exp (\beta)$ & $\beta$ & $\exp (\beta)$ \\
\hline \multicolumn{17}{|c|}{ Individual-Level Variables } \\
\hline \multicolumn{17}{|l|}{ Gender (women) } \\
\hline Men & 0.074 & 1.07 & 0.013 & 1.013 & 0.007 & 1.007 & 0.010 & 1.01 & 0.02 & 1.03 & 0.03 & 1.03 & 0.04 & 1.04 & 0.03 & 1.03 \\
\hline $\begin{array}{l}\text { Age (mean-centered: 22.07) } \\
\text { Residence area (urban) }\end{array}$ & -0.013 & 0.98 & -0.045 & 0.95 & -0.044 & 0.956 & -0.045 & 0.95 & -0.04 & 0.96 & -0.03 & 0.97 & -0.048 & 0.95 & -0.06 & 0.94 \\
\hline $\begin{array}{l}\text { Residence area (urban) } \\
\text { Rural }\end{array}$ & -0.400 & 0.67 & $-0.392 *$ & 0.675 & $-0.389 *$ & 0.677 & -0.392 * & 0.67 & -0.39 & 0.66 & -0.374 & 0.69 & -0.384 & 0.68 & -0.36 & 0.69 \\
\hline $\begin{array}{l}\text { Final grade } \\
\text { (mean-centered: 8.81) }\end{array}$ & 0.250 * & 1.28 & $0.261^{* *}$ & 1.29 & $0.261 * *$ & 1.29 & $0.261 *$ & 1.30 & $0.27^{* *}$ & 1.31 & $0.275^{* *}$ & 1.32 & $0.266^{* *}$ & 1.30 & $0.26 * *$ & 1.29 \\
\hline \multicolumn{17}{|l|}{ Father's highest level of education (low) } \\
\hline Medium & 0.308 & 1.36 & 0.248 & 1.28 & 0.250 & 1.28 & 0.252 & 1.28 & 0.26 & 1.29 & 0.277 & 1.32 & 0.172 & 1.18 & 0.13 & 1.14 \\
\hline \multirow{2}{*}{\multicolumn{17}{|c|}{ Subjective income (easy) }} \\
\hline & & & & & & & & & & & & & & & & \\
\hline \multicolumn{15}{|l|}{ Working contract type (not working) } & & \\
\hline Full-time & $1.073^{* * *}$ & 2.92 & $1.03^{* * *}$ & 2.80 & $1.02^{* * *}$ & 2.77 & $1.025^{* * *}$ & 2.78 & $1.04^{* * *}$ & 2.83 & $1.04^{* * *}$ & 2.83 & $1.11^{* * *}$ & 3.02 & $1.11^{* * *}$ & 3.04 \\
\hline Part-time & 0.374 & 1.45 & 0.369 & 1.44 & 0.363 & 1.43 & 0.365 & 1.44 & 0.37 & 1.44 & 0.37 & 1.45 & 0.382 & 1.46 & 0.38 & 1.46 \\
\hline $\begin{array}{l}\text { Seniority } \\
\text { (mean-centered:0.91) }\end{array}$ & $-0.244^{* *}$ & 0.78 & $-0.231 * *$ & 0.79 & $-0.229^{* *}$ & 0.79 & $-0.231^{* *}$ & 0.79 & $-0.23 * *$ & 0.79 & $-0.223 * *$ & 0.79 & $-0.225^{* *}$ & 0.79 & $-0.22 * *$ & 0.79 \\
\hline $\begin{array}{l}\text { Master's degree graduate full-time salary } \\
\text { (mean-centered: } 3815 \text { ) }\end{array}$ & 0.0001 & 1.00 & 0.00009 & 1.00 & 0.0001 & 1.00 & 0.0001 & 1.00 & 0.0001 & 1.00 & 0.0001 & 1.00 & 0.0001 & 1.00 & 0.00001 & 1.00 \\
\hline $\begin{array}{l}\text { Master's degree unemployed proportion } \\
\text { (mean-centered:10.04) }\end{array}$ & 0.006 & 1.00 & 0.00438 & 1.00 & 0.0046 & 1.00 & 0.0045 & 1.00 & 0.004 & 0.99 & 0.004 & 0.99 & 0.002 & 0.99 & 0.002 & 1.00 \\
\hline \multicolumn{17}{|c|}{ University-Level Variables } \\
\hline \multicolumn{17}{|l|}{ University type (engineering) } \\
\hline 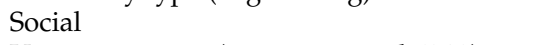 & & & $-0.269 *$ & 0.763 & $-0.274^{*}$ & 0.76 & $-0.272 *$ & 0.761 & $-0.29 *$ & 0.74 & $-0.32 * * *$ & 0.72 & $-0.65^{* * *}$ & 0.52 & $-0.78^{* * *}$ & 0.46 \\
\hline University score (mean-centered: 5.89) & & & $0.047^{*}$ & 1.05 & & & & & $0.06^{* *}$ & 1.06 & 0.067 * & 1.06 & $0.049 *$ & 1.05 & $0.054^{* *}$ & 1.05 \\
\hline $\begin{array}{l}\text { Student number in the master's programs } \\
\text { (mean-centered: } 4582 \text { ) }\end{array}$ & & & & & 0.0001 & 1.00 & & & & & & & & & & \\
\hline $\begin{array}{l}\text { Number of master's programs } \\
\text { (mean-centered: 112) }\end{array}$ & & & & & & & 0.003 & 1.00 & & & & & & & & \\
\hline \multicolumn{17}{|c|}{ County-level Variables } \\
\hline $\begin{array}{l}\text { Students enrolled in bachelor studies, } \\
\text { full-time education, \% of total students } \\
\text { enrolled in bachelor studies }\end{array}$ & & & & & & & & & $-0.21 *$ & 0.81 & & & & & & \\
\hline $\begin{array}{l}\text { Engineering univ.* } \\
\text { Students enrolled in bachelor studies, \% }\end{array}$ & & & & & & & & & $0.03 *$ & 1.02 & & & & & & \\
\hline $\begin{array}{l}\text { Participation rate in education } \\
\text { and training }\end{array}$ & & & & & & & & & & & $3.054^{* *}$ & 21.21 & & & & \\
\hline
\end{tabular}


Table 3. Cont.

\begin{tabular}{|c|c|c|c|c|c|c|c|c|c|c|c|c|c|c|c|c|}
\hline & \multicolumn{2}{|c|}{ Model I } & \multicolumn{2}{|c|}{ Model II } & \multicolumn{2}{|c|}{ Model III } & \multicolumn{2}{|c|}{ Model IV } & \multicolumn{2}{|c|}{ Model V } & \multicolumn{2}{|c|}{ Model VI } & \multicolumn{2}{|c|}{ Model VII } & \multicolumn{2}{|c|}{ Model VIII } \\
\hline & $\beta$ & $\exp (\beta)$ & $\beta$ & $\exp (\beta)$ & $\beta$ & $\exp (\beta)$ & $\beta$ & $\exp (\beta)$ & $\beta$ & $\exp (\beta)$ & $\beta$ & $\exp (\beta)$ & $\beta$ & $\exp (\beta)$ & $\beta$ & $\exp (\beta)$ \\
\hline \\
\hline $\begin{array}{l}\text { Participation rate in education and } \\
\text { training }\end{array}$ & & & & & & & & & & & $-0.268^{*}$ & 0.88 & & & & \\
\hline Average gross earnings & & & & & & & & & & & & & $\underset{* * *}{-0.0017}$ & 0.99 & $\underset{* * *}{-0.0022}$ & 0.99 \\
\hline $\begin{array}{l}\text { Engineering univ. }{ }^{*} \\
\text { Average gross earnings }\end{array}$ & & & & & & & & & & & & & $0.0073^{* *}$ & 1.00 & $0.0008^{* * *}$ & 1.00 \\
\hline Empl_htc & & & & & & & & & & & & & $0.417^{* * *}$ & 1.51 & & \\
\hline Constant & -0.165 & 0.85 & 0.455 & 2.06 & 0.698 & 2.01 & 0.733 & 1.72 & 0.64 & 1.91 & 0.563 & 1.75 & 0.981 & 2.66 & $1.44^{* * *}$ & 4.24 \\
\hline Observations & 476 & & 476 & & 476 & & 476 & & 476 & & 476 & & 476 & & 476 & \\
\hline No. Of groups & 10 & & 10 & & 10 & & 10 & & 10 & & 10 & & 10 & & 10 & \\
\hline No. Of counties & 5 & & 5 & & 5 & & 5 & & 5 & & 5 & & 5 & & 5 & \\
\hline Log likelihood & -300.89 & & -299.91 & & -300.05 & & -300.08 & & -299.91 & & -300.05 & & -300.08 & & -294.50 & \\
\hline \multicolumn{17}{|c|}{ Random-Effects Parameters } \\
\hline County variance (cons) & 0.23 & & 0.19 & & 0.18 & & 0.17 & & 0.17 & & 0.16 & & 0.26 & & 0.15 & \\
\hline University variance (cons) & 0.809 & & 0.74 & & 0.75 & & 0.76 & & 0.56 & & 0.42 & & 0.95 & & 0.97 & \\
\hline Vpc at university level ${ }^{1}(\%)$ & $19.77 \%$ & & $18.36 \%$ & & $18.56 \%$ & & $18.76 \%$ & & $14.54 \%$ & & $11.32 \%$ & & $22.40 \%$ & & $22.76 \%$ & \\
\hline \multirow{2}{*}{ Lr test } & \multicolumn{2}{|c|}{ Model IX } & \multicolumn{2}{|c|}{ Model X } & \multicolumn{2}{|c|}{ Model XI } & \multicolumn{2}{|c|}{ Model XII } & \multicolumn{2}{|c|}{ Model XIII } & \multicolumn{2}{|c|}{ Model XIV } & \multicolumn{2}{|c|}{ Model XV } & \multicolumn{2}{|c|}{ Model XVI } \\
\hline & $\beta$ & $\exp (\beta)$ & $\beta$ & $\exp (\beta)$ & $\beta$ & $\exp (\beta)$ & $\beta$ & $\exp (\beta)$ & $\beta$ & $\exp (\beta)$ & $\beta$ & $\exp (\beta)$ & $\beta$ & $\exp (\beta)$ & $\beta$ & $\exp (\beta)$ \\
\hline \multicolumn{17}{|c|}{ Individual-Level Variables } \\
\hline \multicolumn{17}{|l|}{ Gender (women) } \\
\hline Men & 0.038 & 1.04 & 0.078 & 1.08 & 0.063 & 1.06 & 0.037 & 1.03 & 0.038 & 1.03 & 0.06 & 1.06 & 0.06 & 1.06 & 0.052 & 1.05 \\
\hline $\begin{array}{l}\text { Age (mean-centered: 22.07) } \\
\text { Residence area (urban) }\end{array}$ & -0.052 & 0.95 & -0.048 & 0.95 & -0.049 & 0.951 & -0.051 & 0.95 & -0.54 & 0.94 & -0.03 & 0.97 & -0.046 & 0.95 & -0.046 & 0.95 \\
\hline Rural & -0.376 & 0.68 & -0.367 * & 0.692 & $-0.376^{*}$ & 0.686 & $-0.373 *$ & 0.68 & -0.36 & 0.69 & -0.407 & 0.66 & -0.385 & 0.68 & -0.39 & 0.68 \\
\hline $\begin{array}{l}\text { Final grade } \\
\text { (mean-centered: } 8.81)\end{array}$ & $0.263^{* *}$ & 1.30 & $0.314^{* *}$ & 1.37 & $0.296^{* *}$ & 1.34 & $0.265 *$ & 1.30 & $0.26^{* *}$ & 1.30 & $0.287^{* *}$ & 1.33 & $0.293 * *$ & 1.34 & $0.28^{* *}$ & 1.32 \\
\hline \multicolumn{17}{|l|}{ Father's highest level of education (low) } \\
\hline Medium & 0.174 & 1.19 & 0.245 & 1.27 & 0.209 & 1.23 & 0.219 & 1.24 & 0.20 & 1.22 & 0.212 & 1.23 & 0.196 & 1.21 & 0.17 & 1.18 \\
\hline $\begin{array}{l}\text { High } \\
\text { Subiective income (easv) }\end{array}$ & $0.650 * *$ & 1.91 & $0.648^{*}$ & 1.91 & $0.654 *$ & 1.92 & $0.666^{*}$ & 1.94 & $0.65 *$ & 1.91 & $0.690 *$ & 1.99 & $0.660 *$ & 1.93 & $0.66^{*}$ & 1.93 \\
\hline $\begin{array}{l}\text { Hard } \\
\text { Working contract type (not working) }\end{array}$ & 0.203 & 1.22 & 0.231 & 1.26 & 0.219 & 1.24 & 0.203 & 1.22 & 0.20 & 1.22 & 0.220 & 1.25 & 0.218 & 1.24 & 0.21 & 1.23 \\
\hline Full-time & $1.01^{* * *}$ & 3.00 & $1.14^{* * *}$ & 1.27 & $1.15^{* * *}$ & 3.16 & $1.074^{* * *}$ & 2.92 & $1.08^{* * *}$ & 2.96 & $1.11^{* * *}$ & 3.03 & $1.15^{* * *}$ & 3.16 & $1.14^{* * *}$ & 3.13 \\
\hline
\end{tabular}


Table 3. Cont.

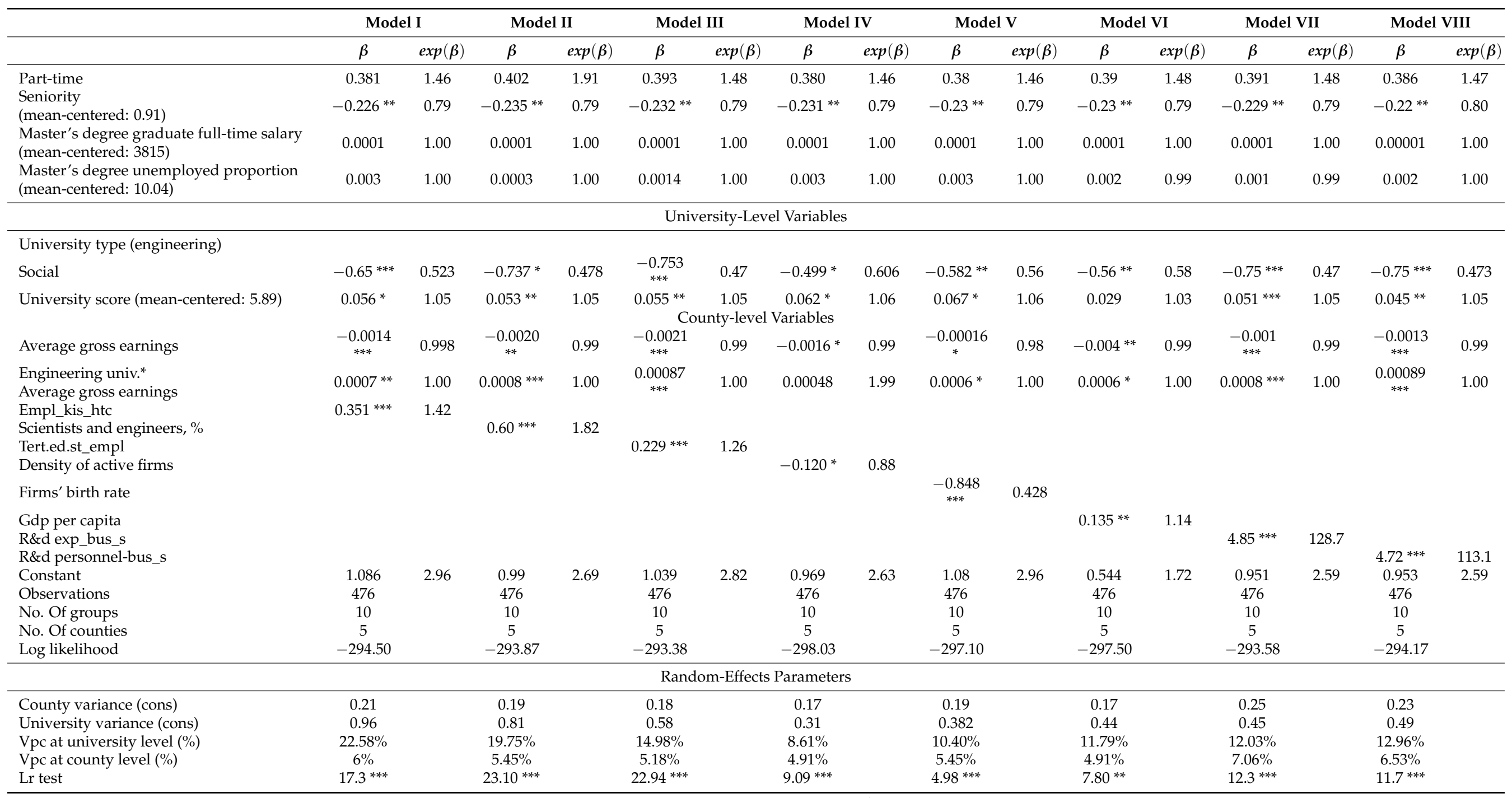

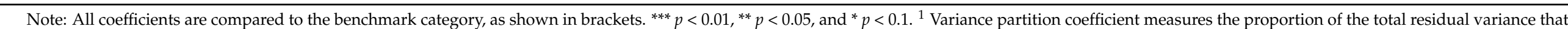
is due to between-group variation. 
Table 4. Multilevel mixed-effects logistic regression models (random intercept models) of the enrolment decision of Romanian students to a master's program.

\begin{tabular}{|c|c|c|c|c|}
\hline & \multicolumn{2}{|c|}{ Model XVII } & \multicolumn{2}{|c|}{ Model XVIII } \\
\hline & $\beta$ & $\exp (\beta)$ & $\beta$ & $\exp (\beta)$ \\
\hline \multicolumn{5}{|c|}{ Individual-Level Variables } \\
\hline \multicolumn{5}{|l|}{ Gender (women) } \\
\hline Men & 0.054 & 1.05 & 0.047 & 1.05 \\
\hline Age (mean-centered: 22.07) & -0.04 & 0.96 & -0.044 & 0.95 \\
\hline \multicolumn{5}{|l|}{ Residence area (urban) } \\
\hline Rural & -0.389 & 0.68 & $-0.383 *$ & 0.68 \\
\hline $\begin{array}{c}\text { Final grade } \\
\text { (mean-centered: } 8.81 \text { ) }\end{array}$ & $0.247^{* *}$ & 1.33 & $0.281^{* *}$ & 1.32 \\
\hline \multicolumn{5}{|l|}{ Father's highest level of education (low) } \\
\hline Medium & 0.247 & 1.28 & 0.243 & 1.27 \\
\hline High & $0.684^{* *}$ & 1.98 & 0.679 * & 1.97 \\
\hline \multicolumn{5}{|l|}{ Subjective income (easy) } \\
\hline Hard & 0.22 & 1.24 & 0.214 & 1.24 \\
\hline \multicolumn{5}{|l|}{ Working contract type (not working) } \\
\hline Full-time & $1.08^{* * *}$ & 2.96 & $1.08^{* * *}$ & 294 \\
\hline Part-time & 0.39 & 1.48 & 0.386 & 1.47 \\
\hline $\begin{array}{c}\text { Seniority } \\
\text { (mean-centered: 0.91) }\end{array}$ & $-0.23^{* *}$ & 0.79 & $-0.232^{* *}$ & 0.79 \\
\hline $\begin{array}{l}\text { Master's degree graduate full-time salary } \\
\text { (mean-centered: } 3815 \text { ) }\end{array}$ & 0.0001 & 1.00 & 0.0001 & 1.00 \\
\hline $\begin{array}{l}\text { Master's degree unemployed proportion } \\
\text { (mean-centered: } 10.04 \text { ) }\end{array}$ & 0.002 & 1.00 & 0.0003 & 1.00 \\
\hline \multicolumn{5}{|c|}{ University-Level Variables } \\
\hline \multicolumn{5}{|l|}{ University type (engineering) } \\
\hline Social & $-0.48^{* * *}$ & 0.613 & $-0.472 *$ & 0.62 \\
\hline University score (mean-centered: 5.89) & $0.041 *$ & 1.04 & $0.047^{* *}$ & 1.05 \\
\hline \multicolumn{5}{|c|}{ County-level Variables } \\
\hline Average gross earnings & $-0.002^{* * *}$ & 0.998 & $-0.003^{* *}$ & 0.99 \\
\hline $\begin{array}{l}\text { Engineering univ. }{ }^{*} \\
\text { Average gross earnings }\end{array}$ & 0.0005 * & 1.00 & $0.0005 *$ & 1.00 \\
\hline Innovative enterp. & -0.114 * & 0.89 & & \\
\hline Only produs innovators & & & $-0.86 *$ & 0.42 \\
\hline Constant & 0.68 & 1.98 & 0.78 & 2.19 \\
\hline Observations & 476 & & 476 & \\
\hline No. Of groups & 10 & & 10 & \\
\hline No. Of counties & 5 & & 5 & \\
\hline Log likelihood & -298.13 & & -298.31 & \\
\hline \multicolumn{5}{|c|}{ Random-Effects Parameters } \\
\hline County variance (cons) & 0.19 & & 0.23 & \\
\hline University variance (cons) & 0.47 & & 0.53 & \\
\hline Vpc at university level (\%) & $12.5 \%$ & & $13.87 \%$ & \\
\hline Vpc at county level (\%) & $5.45 \%$ & & 6.53 & \\
\hline Lr test & $4.3 *$ & & $7.10^{* * *}$ & \\
\hline
\end{tabular}

Note: All coefficients are compared to the benchmark category, as shown in brackets. ${ }^{* * *} p<0.011^{* *} p<0.05$, and ${ }^{*} p<0.1$.

Therefore, in line with question Q4, we can reveal that individual, university, and socio-economic factors interact in shaping students' intentions to pursue master's degrees. Additionally, the empirical results provided enough evidence based on VPC values to claim that the decision of enrolment to a master's program varies across both universities and counties, with a higher magnitude in the case of universities and with a smaller magnitude across counties. 


\subsection{Discussion Based on the Results of the Estimated Models}

In an increasingly knowledge-based globalized world, higher education, advanced training, and skill development are fundamental characteristics of the future. For developing students' skills, universities deliver programs that better prepare them to straightforwardly respond to societal and labor market needs once they graduate by creating, refining, and adapting courses within their undergraduate and graduate programs [31]. To increase the efficacy of the education system, specialized skills need to be developed all throughout the workforce and this can be achieved by providing students with graduate education [32].

Thus, the decision of applying to a master's program can be seen from two perspectives: on the one hand, the decision comes from the students' desire to specialize in their specific field [31]; on the other hand, this decision comes from the desire to supplement their undergraduate degree by generalizing their knowledge with an advanced degree [31].

At the time of hiring, employers assess if a person has the potential for development, wherein the foremost critical aptitude considered when it comes to advancement is the capacity to acquire new skills [33] and for this precise reason, employers are more inclined to hire "demonstrated learners" who have a record of learning through formal instruction [32].

Students consider the importance of pursuing graduate education in relation to expectations from employers to recognize signals sent by graduate degrees and the expected earning premium associated with a graduate degree [32].

In our scientific demarche of investigating what encourages longer educational careers in tertiary education, the empirical results revealed three categories of determinants: individual characteristics, university characteristics, and county particularities.

Therefore, at the individual level, students with higher academic performances, with fathers with a high levels of education, with a working with full-time contract, and without a significant job seniority are more inclined to enroll in a future master's program. These results are consistent with many other research findings [10-14,26,27], showing that previous academic performances and parental education as measures of the cultural capital of students influence educational decisions. Individual characteristics related to labor market participation that act as predictors for enrolment in master's programs are consistent with the human capital theory. Pursuing a higher level of education is seen as a way for acquiring specialized skills valuable in the workplace, especially for those who have no working experience. A summary of our most relevant findings is provided in Figure 3.

As university determinants, previous studies showed that the satisfaction of students with educational experience shapes their predisposition to continue education and this can be highlighted by perceived performances and outcomes of educational institutions [17]. Our empirical evidence pointed out the positive effect of the university performance score on the decision to enroll in a master's program. Another characteristic of influence is the type of university, with students from engineering universities being more inclined to enroll in a master's program. The results subscribe also to other studies that highlight the influence of the context for further pursuing education, with a focus on the quality of education and on the important variations induced by the major on the predisposition to pursue a master's degree. [14-17]. At the county level, three main categories of determinants have been revealed. In terms of educational indicators, we can point out the influence of the proportion of students from engineering universities enrolled in bachelor studies and the participation rate in education and training as the most relevant factors affecting the decision of applying to a master's program. This reveals the importance of participation in learning activities, whether formal, non-formal, or informal, undertaken on an ongoing basis with the aim of improving knowledge, skills, and competences for personal, social, and/or professional reasons. During the course of a person's working life, it is increasingly necessary to develop existing skills and to learn new skills that are relevant to a specific job or which provide opportunities for new career paths. The results are in line with the study of Jiménez and Salas-Velasco [12]. Thus, local contexts with high 
participation in education and training, especially in engineering, are those that provide higher incentives to bachelor students to enroll in master's programs. Our results point to the fact that a higher level of skills at the local level acts as a catalysator for increasing the demand for master-level education among bachelor students. 

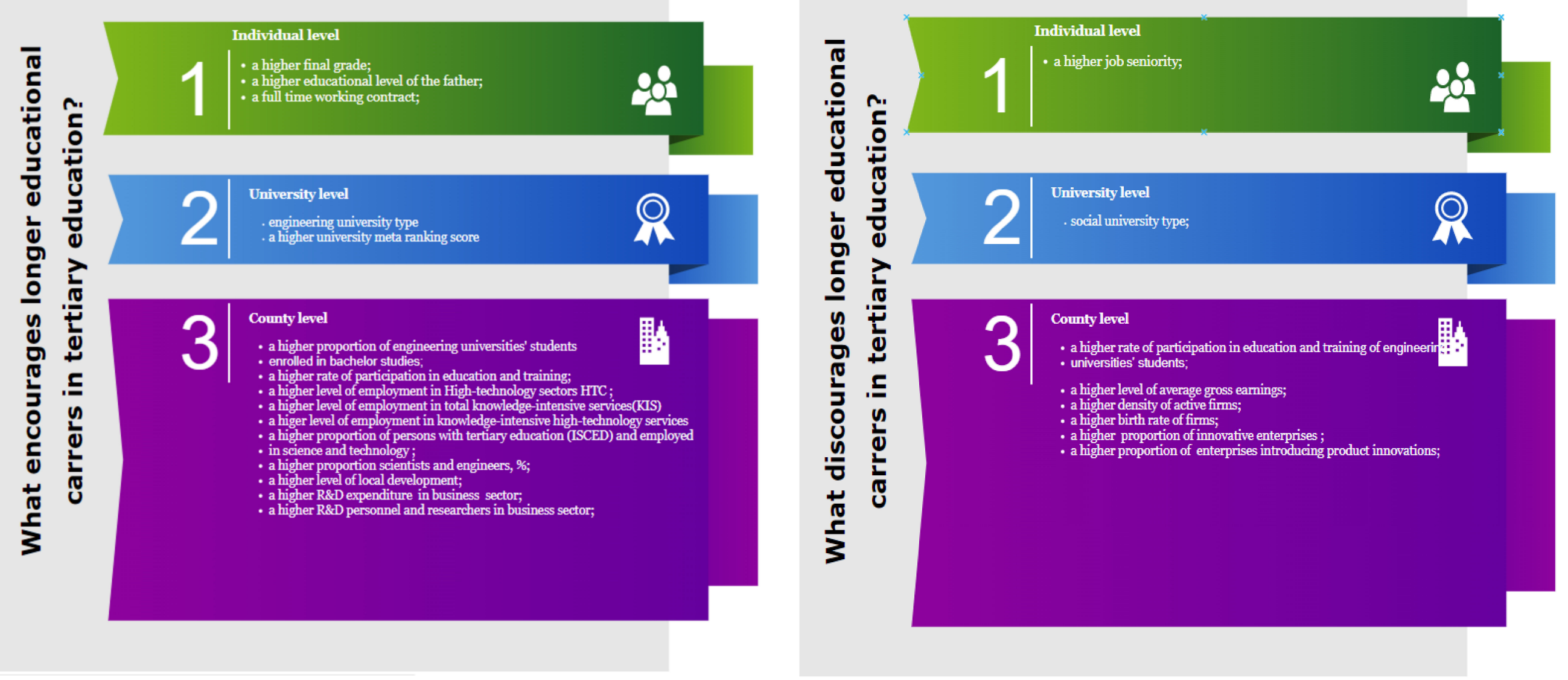

Figure 3. Summary of the main findings of our research. 
A second category of determinants are related to the characteristics of the labor market for highly skilled workers that influence students' decision of enrolment in higher education levels (Kallio, [25]). Among the most relevant factors determining the decision of enrolment into a master's program, we can mention the level of employment in high-technology sectors (HTC), total-knowledge intensive sectors (KIS), and knowledge-intensive hightechnology sectors (KIS_HTC); the proportion of persons with tertiary education employed in science and technology; the proportion of scientists and engineers; the level of local development; and R\&D expenditure and the number of both personnel and researchers in the business sector. All of these determinants positively influence the decisions of students to enroll in a master's program, capturing the formal creation of new knowledge within firms most likely in science-based sectors where most new knowledge is created in or near R\&D laboratories. These results have been confirmed also by the findings of English and Umbach [2], Jiménez and Salas-Velasco [12], and Kallio [25].

The last category of determinants is related to the characteristics of the business sector that influence students' decision of enrolment in higher education levels (Kallio, [25]). Thus, factors such as the average gross earnings, the density of active firms together with the birth rate of companies, and the proportion of innovative enterprises or those introducing product innovations tend to decrease the probability of continuing the educational career, attracting students to the labor market. The results found their confirmation in the studies of Jiménez and Salas-Velasco [12] as well as Kallio [25].

The birth of new enterprises is often seen as one of the key determinants of job creation and economic growth. Enterprise births are thought to increase the competitiveness of a country's enterprise population by obliging them to become more efficient in view of newly emerging competition. As such, they stimulate innovation and facilitate the adoption of new technologies, while helping to increase the overall productivity within an economy. Therefore, an innovative business sector could offer alternative incentives to Romanian students who become less inclined to follow the courses of a master's program.

What it is important to point out is the fact that average gross earnings and the dynamics of innovations in the business sector have been found as most likely to decrease the probability of continuing the educational career, but the marginal effect of these determinants depends on the university type. However, students from engineering universities with high earnings working in innovative enterprises or introducing product innovations are more inclined to enroll in a master's program in the near future. In sum, our findings enrich the human capital theory with respect to enrolment in master's programs, suggesting that students from more knowledge-intensive economic contexts anticipate higher returns from the further accumulation of highly specialized skills provided by master's programs, while dynamic economic environments that are not very knowledge-oriented provide satisfactory employment opportunities and earnings for graduates of bachelor studies, discouraging them to further invest in acquiring master-level skills. Our study confirms the human capital theory by showing that individuals are more willing to invest in acquiring specialized skills in contexts of high demand of such skills and are thus able to return their investment.

Since the main limitation of the study refers to the inclusion of only five counties, future research studies will take into account a higher number of universities and counties, applying two essential methods of feature selection, namely chi-squared testand mutual information, both having as a main specificity the fact that output variables and input variables are categorical. The feature selection is the process of reducing or decreasing the number of input variables while expanding a prediction or classification model and it involves the evaluation of the relationship between the target feature and each input feature following statistics.

\section{Conclusions}

Students' commitment and engagement in the educational process are shaped by a dense combination of factors, with effects on educational attainment and on the length 
of their educational careers. Decisions of prolonging education by enrolling in master's degrees are beneficial for both individuals and societies as such programs provide higher levels of specialized skills [2]. Longer educational careers are favored by a mix of factors acting at the level of individual, university, or wider environment. The main aim of our research has been to identify which are the main factors at the level of counties, universities, and that of students, which determine the likelihood of master's program enrolment in Romania.

The empirical results revealed that the academic performance, the father's level of education, the type of working contract, and the job seniority are individual-level determinants influencing the decision of enrolment in a master's program. At the university level, the type of university and the university performance score positively impact the students' decision to enroll in a master's program.

At the county level, the empirical evidence pointed out the significance of determinants such as the proportion of students enrolled in bachelor studies; participation rate in education and training; employment level in high-technology sectors (HTC), totalknowledge intensive sectors (KIS), and knowledge-intensive high-technology sectors (KIS_HTC); proportion of persons with tertiary education employed in science and technology; proportion of scientists and engineers; local development; R\&D expenditure and both personnel and researchers in the business sector; average gross earnings; density of active firms; birth rate of companies; and proportion of innovative enterprises or those introducing product innovations on the decision to enroll in a master's program. These findings show that the demand for master-level education is driven by knowledge-intensive economic contexts and environments characterized by the expansion of education and quality educational programs, while predisposition to further continue education is higher among highly academic performers and those coming from families with a higher stock of education. The results are relevant for Romanian universities that can improve the relevance of their master's programs in relation to the needs of other students and to the characteristics of the wider economic and social environment in order to improve enrolment in their master's programs. Potential future studies will aim to extend the research at the level of more countries, especially for assessing the factors shaping enrolment in master's programs within various educational systems and economic settings.

Author Contributions: Conceptualization, A.-M.Z., A.A.D. and C.M.; methodology, A.-M.Z., A.A.D. and C.M.; software, A.A.D.; validation, A.-M.Z., A.A.D. and C.M.; formal analysis, A.-M.Z., A.A.D. and C.M.; investigation, A.-M.Z., A.A.D. and C.M.; data curation, A.-M.Z. and C.M.; writingoriginal draft preparation, A.-M.Z., A.A.D. and C.M.; writing-review and editing, A.-M.Z., A.A.D. and C.M.; visualization, A.-M.Z., A.A.D. and C.M.; supervision, A.A.D.; project administration, A.-M.Z.; funding acquisition, A.-M.Z. All authors have read and agreed to the published version of the manuscript.

Funding: This research study was funded by the Ministry of Research, Innovation, and Digitalization, NUCLEU program, project number PN 19130301. Part of the APC was funded by the Ministry of Research, Innovation, and Digitalization, NUCLEU program, project number PN 19130301.

Institutional Review Board Statement: The study was conducted according to the Code of Ethics and Integrity of the National Scientific Research Institute for Labour and Social Protection, and approved by the Internal Approval Commission of the Scientific Board of National Scientific Research Institute for Labour and Social Protection (No. 1337/09.12.2019).

Informed Consent Statement: Informed consent was obtained from all subjects involved in the study.

Data Availability Statement: The survey dataset is available upon request. University statistics are available in Metarankingul Universitar-2019. Clasamentul Universităților din România, available on https:/ / ad-astra.ro/wp-content/uploads/2019/11/Metarankingul_Universitar_2019.pdf (accessed on 10 August 2021). County and regional-level indicators are available on the Territorial Statistics and Tempo databases of the National Institute of Statistics (NIS) as well as on Eurostat databases.

Conflicts of Interest: The authors declare no conflict of interest. 


\section{References}

1. Proiectul, Agenda Pentru Competențe ROMÂNIA 2020, 2025. Available online: https://mmuncii.ro/j33/images / Documente/ MMPS/Rapoarte_si_studii_MMPS/DPOCM/Agenda_pentru_competente_ROMANIA_2020-2025R5etapaIII.pdf (accessed on 24 November 2021).

2. English, D.; Umbach, P.D. Graduate School Choice: An Examination of Individual and Institutional Effects. Rev. High. Educ. 2016, 39, 173-211. [CrossRef]

3. Poock, M.C.; Love, P.G. Factors influencing the program choice of doctoral students in higher education administration. NASPA J 2001, 38, 203-223. [CrossRef]

4. Lei, S.A.; Chuang, N. Demographic factors influencing selection of an ideal graduate institution: A literature review with recommendations for implementation. Coll. Stud. J. 2010, 44, 84-96.

5. Baum, S.; Ma, J.; Payea, K. Education Pays: The Benefits of Higher Education for Individuals and Society; College Board: Washington, DC, USA, 2010.

6. Vu, L.T.H.; Le, L.C.; Muhajarine, N. Multilevel Determinants of Colleges/Universities Enrolment in Vietnam: Evidences from the 15\% Sample Data of Population Census 2009. Soc. Indic. Res. 2012, 111, 375-386. [CrossRef]

7. Hossler, D.; Gallagher, K. Studying student college choice: A three-phase model and the implications for policymakers. Coll. Univ. 1987, 62, 207-221.

8. Latiesa, M. Demanda de educación superior: Evaluaciones y condicionamientos de los estudiantes en la elección de carrera. REIS 1989, 46, 101-139. [CrossRef]

9. Mullen, A.L.; Goyette, K.A.; Soares, J.A. Who Goes to Graduate School? Social and Academic Correlates of Educational Continuation after College. Sociol. Educ. 2003, 76, 143. [CrossRef]

10. Schapiro, M.O.; O'Malley, M.P.; Litten, L.H. Progression to graduate school from the "Elite" colleges and universities. Econ. Educ. Rev. 1991, 10, 227-244. [CrossRef]

11. González, B.; Dávila, D. Economic and cultural impediments to university education in Spain. Econ. Educ. Rev. 1998, 17, 93-103.

12. Jiménez, J.D.D.; Salas-Velasco, M. Modeling educational choices. A binomial logit model applied to the demand for Higher Education. High. Educ. 2000, 40, 293-311. [CrossRef]

13. Perna, L.W. Understanding the decision to enroll in graduate school: Sex and racial/ethnic group differences. J. High. Educ. 2004, 75, 487-527. [CrossRef]

14. Jung, J.; Lee, S.J. Exploring the factors of pursuing a master's degree in South Korea. High. Educ. 2019, 78, 855-870. [CrossRef]

15. Tinto, V. Dropout from higher education: A theoretical synthesis of recent research. Rev. Educ. Res. 1975, 45, 89-125. [CrossRef]

16. Zhang, L. Advance to Graduate Education: The Effect of College Quality and Undergraduate Majors. Rev. High. Educ. 2005, 28, 313-338. [CrossRef]

17. Hartman, D.E.; Schmidt, S.L. Understanding student/alumni satisfaction from a consumer's perspective: The effects of institutional performance and program outcomes. Res. High. Educ. 1995, 36, 197-217. [CrossRef]

18. Becker, G.S. Investment in Human Capital: A Theoretical Analysis. J. Politi-Econ. 1962, 70, 9-49. [CrossRef]

19. Thomas, S.L.; Perna, L.W. The opportunity. In Higher Education: Handbook of Theory and Research; Smart, J.C., Ed.; Springer: Dordrecht, The Netherlands, 2004; Volume XIX, pp. 43-84.

20. Paulsen, M.B.; Toutkoushian, R.K. Economic models and policy analysis in higher education: A diagrammatic exposition. In Higher Education: Handbook of Theory and Research; Smart, J.C., Ed.; Springer: Dordrecht, The Netherlands, 2008; Volume XXIII, pp. 1-48.

21. Ashenfelter, O.; Ham, J. Education, unemployment and earnings. J. Political Econ. 1979, 87, S99-S116. [CrossRef]

22. Handa, M.L.; Skolnik, M.L. Unemployment, expected returns, and the demand for university education in Ontario: Some empirical results. High. Educ. 1975, 4, 27-43. [CrossRef]

23. Kodde, D.A. Uncertainty and the Demand for Education. Rev. Econ. Stat. 1986, 68, 460-467. [CrossRef]

24. Maer-Matei, M.M. Measures of Occupational Mismatch. SEA-Pract. Appl. Sci. 2014, 5, 425-430.

25. Kallio, R.E. Factors influencing the college choice decisions of graduate students. Res. High. Educ. 1995, 36, 109-124. [CrossRef]

26. Beyene, K.M.; Yimam, J.A. Multilevel Analysis for Identifying Factors Influencing Academic Achievement of Students in Higher Education Institution: The Case of Wollo University. J. Educ. Pract. 2016, 7, 17-23.

27. Sturm, K. Factors Students Consider in the Decision-Making Process for Graduate Education. Master's Theses, Eastern Illinois University, Charleston, IL, USA, 2019. Available online: https:/ thekeep.eiu.edu/theses/4315/ (accessed on 23 November 2021).

28. McFadden, D. Conditional Logit Analysis of Qualitative Choice Behavior. In Frontiers in Econometrics; Zarembka, P., Ed.; Academic Press: New York, NY, USA, 1974; pp. 105-142.

29. Leckie, G. Three-Level Multilevel Models-Stata Practical. LEMMA VLE Modul. 2013, 11, 1-45. Available online: http:/ /www. bristol.ac.uk/cmm/learning/course.html (accessed on 23 July 2021).

30. Stata 15 Software, StataCorp LLC. College Station, TX, USA. Available online: https:/ / www.stata.com/ (accessed on 3 July 2021).

31. Jepsen, D.M.; Varhegyi, M.M. Awareness, knowledge and intentions for postgraduate study. J. High. Educ. Policy Manag. 2011, 33, 605-617. [CrossRef]

32. Stewart, D. "Important if true": Graduate education will drive America's future prosperity. Change 2010, 42, 36-44. [CrossRef]

33. Carnevale, A.P. Graduate education in 2020: What Does the Future Hold? Council of Graduate Schools: Washington, DC, USA, 2009. 